\title{
The effect of starch source on physicochemical and sensory quality of veal meat
}

\author{
E.M. Sosin-Bzducha ${ }^{1,4}$, J.A. Strzetelski ${ }^{2}$ and G. Skrzyński ${ }^{3}$ \\ National Research Institute of Animal Production, \\ ${ }^{1}$ Department of Animal Genetic Resources Conservation, \\ ${ }^{2}$ Department of Animal Nutrition and Feed Science \\ 32-083 Balice, Poland \\ ${ }^{3}$ University of Agriculture in Kraków, Department of Cattle Breeding \\ Al. Mickiewicza 24/28, 30-059 Kraków, Poland
}

(Received 31 January 2012; revised version 9 July 2012; accepted 29 August 2012)

\begin{abstract}
The influence on veal meat quality of replacing barley grain or dry maize ( $50 \%$ by weight) in feed mixtures for calves with ensiled high-moisture maize grain was investigated. Sixteen veal calves were assigned to 4 equal groups. No differences were found among the groups in the nutrient content of Musculus longissimus thoracis. The intramuscular fat of calves from groups fed ensiled maize grain was characterized by lower saturated fatty acids (SFA) and higher unsaturated fatty acid (UFA) contents compared with calves from groups receiving barley or dry maize grain (B, $\mathrm{MD})$, but the differences were not significant $(\mathrm{P}=0.12)$. Calves fed with maize grain (dry or ensiled) had a lower monounsaturated (MUFA) to SFA ratio ( 0.68 vs $0.83 \pm 0.01 ; \mathrm{P}=0.03$ ). Evaluation of the physicochemical properties of muscle meat showed that the analysed starch sources had no effect $(\mathrm{P}>0.05)$ on cooking loss and on $\mathrm{pH}$ measured $24 \mathrm{~h}$ and 7 days post-mortem. There were no differences between the groups in the other physicochemical characteristics of meat, i.e. tenderness and colour.
\end{abstract}

KEY WORDS: calf, veal, starch, quality, fatty acids

\section{INTRODUCTION}

Different starch sources digested in different parts of the digestive tract can affect meat quality in veal calves. Barley, oats and wheat are almost completely digested in the rumen, while ruminal degradation of dry maize grain is slower,

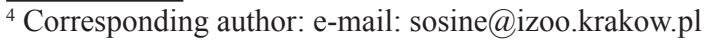


with much more starch passing into the small intestine (Huntington, 1997). Compared with dry grain, high-moisture maize grain subjected to ensiling is more rapidly fermented in the rumen to volatile fatty acids (VFA), with smaller amounts of this grain reaching the small intestine. In the intestine, high-moisture maize grain is better digested than dry grain, and less undigested starch passes into the large intestine; this may be associated with lower faecal starch losses (Archibeque et al., 2006). According to Knowlton et al. (2000), the energy value of ensiled maize grain $(70 \% \mathrm{DM})$ is about $15 \%$ greater than that of dry grain $(>85 \% \mathrm{DM})$. In cattle, most of the unsaturated fatty acids released during lipolysis are biohydrogenated, as a result of which beef has a lower proportion of unsaturated acids compared with poultry or pig meat (Hocquette and Bauchart, 1999). Feeding high amounts of concentrate feeds decreases rumen content $\mathrm{pH}$ and thus reduces lipolysis and biohydrogenation (Doreau and Ferlay, 1994).

The aim of the study was to determine the effect of replacing barley grain or dry maize ( $50 \%$ by weight) in feed mixtures for calves with ensiled high-moisture maize grain on veal meat quality, i.e. on: chemical composition, physicochemical and sensory properties, and the fatty acid profile of intramuscular fat.

\section{MATERIAL AND METHODS}

\section{Animals and feeding}

The experiment was carried out with 16 Polish Holstein-Friesian bull calves aged between $10 \pm 3$ and 90 days, which were assigned based on the analogue principle to 4 equal groups. Calves were given colostrum and whole milk before the experiment, and milk replacer from the beginning of the experiment to 56 days of age. Grains in the mixtures were given in rolled form. The main sources of dietary starch were barley in the control group (B), dry maize grain in group $\mathrm{MD}, 50 \%$ barley and $50 \%$ ensiled maize grain in group BMS, and $50 \%$ dry maize grain and 50\% ensiled maize grain in group MDMS (Table 1). In addition, each mixture contained similar amounts of oats, soyabean meal (SBM), and mineral components. Mixtures with ensiled maize grain (groups BMS and MDMS) were prepared directly before feeding by mixing ensiled maize grain and a supplementary mixture (prepared separately in a feed mixing plant) containing dry grain, SBM and minerals (1:2.5). At the end of the experiment the bulls were slaughtered after 24-h feed withdrawal.

Samples of meat from Musculus longissimus thoracis (MT) were taken from the right side of the carcass $24 \mathrm{~h}$ after slaughter. 
Table 1. The components (as fed), chemical composition and nutritive value of concentrates

\begin{tabular}{|c|c|c|c|c|}
\hline \multirow{2}{*}{ Indices } & \multicolumn{4}{|c|}{ Groups $^{1}$} \\
\hline & B & $\mathrm{M}_{\mathrm{D}}$ & $\mathrm{BM}_{\mathrm{S}}$ & $\mathrm{M}_{\mathrm{D}} \mathrm{M}_{\mathrm{S}}$ \\
\hline \multicolumn{5}{|c|}{ Concentrate composition, $\%$} \\
\hline barley & 57 & - & 28.5 & - \\
\hline maize grain, dry & - & 56 & - & 28.5 \\
\hline maize grain, ensiled & - & - & 28.5 & 28.5 \\
\hline oats & 18 & 18 & 19 & 18 \\
\hline soyabean meal & 21 & 22 & 20 & 21 \\
\hline premix CJ Komplet $^{2}$ & 3 & 3 & 3 & 3 \\
\hline limestone & 1 & 1 & 1 & 1 \\
\hline \multicolumn{5}{|c|}{ Chemical composition, \% of DM } \\
\hline dry matter & 88.6 & 87.2 & 83.9 & 83.7 \\
\hline crude protein & 19.0 & 18.4 & 18.8 & 18.8 \\
\hline ether extract & 2.5 & 3.7 & 2.7 & 8.6 \\
\hline crude fibre & 5.5 & 4.5 & 5.0 & 12.1 \\
\hline starch & 41.1 & 48.9 & 46.0 & 49.5 \\
\hline $\mathrm{N}$-free extractives & 28.5 & 24.3 & 24.3 & 7.71 \\
\hline ash & 3.4 & 3.2 & 3.2 & 3.3 \\
\hline \multicolumn{5}{|c|}{ Nutritive value, in $1 \mathrm{~kg} D M$} \\
\hline PDIN, g & 128 & 130 & 125 & 129 \\
\hline PDIE, $\mathrm{g}$ & 113 & 111 & 105 & 106 \\
\hline UFL & 1.04 & 1.10 & 1.06 & 1.10 \\
\hline
\end{tabular}

\section{Chemical analyses of feeds and biological material}

The nutrient content of feed, feed refusals, and meat samples were determined according to AOAC (1997). Fatty acids were determined after centrifugation of water filtrates with metaphosphoric acid (5:1) using a VARIAN 3400 chromatograph (column CP-Wax $58,25 \mathrm{~m} \times 0.53 \mathrm{~mm}$, injection volume $1.0 \mu \mathrm{l}$; temperature programme $90-200^{\circ} \mathrm{C}$; injector temperature $200^{\circ} \mathrm{C}$; detector temperature $260^{\circ} \mathrm{C}$; helium as the carrier gas) using an $8200 \mathrm{CX}$ autosampler and a computer data processing system. Physicochemical and organoleptic analysis of meat was performed according to Skrzyński et al. (2001). pH was measured using a pH-Star CPU device (Matthäus) $24 \mathrm{~h}$ and 7 days after slaughter. Meat colour was determined in the CIE $L^{*} a^{*} b$ system (Boccard et al., 1981) using a Minolta CR 310 chroma meter 24 and $48 \mathrm{~h}$ after slaughter. After $48 \mathrm{~h}$ storage thermal loss and tenderness of meat were measured. Meat samples were sliced into $1.5 \mathrm{~cm}$ thick steaks and cooked in an electric cooker at $165^{\circ} \mathrm{C}$ to an internal temperature of $70^{\circ} \mathrm{C}$. Sensory evaluation of meat (i.e., aroma, palatability, juiciness, and tenderness) was performed according to a 5-point scale (Baryłko-Pikielna, 1975).

\section{Statistical analysis}

Results were analysed using Enterprise Guide SAS 4.1 (2002) one-way analysis 
of variance (ANOVA procedure) and Duncan's multi-range test with differences considered significant at $\mathrm{P} \leq 0.05$.

\section{RESULTS}

The results for body weight, feed intake and volatile fatty acids (VFA) as well as rumen development parameters were published in Sosin-Bzducha et al. (2010).

\section{Chemical composition of feeds}

The diets contained similar levels of protein and energy and contained (per kg DM) an average of: $187 \pm 3 \mathrm{~g}$ crude protein, $109 \pm 4.0 \mathrm{~g}$ PDI, $1.07 \pm 0.03$ UFL. Diets for groups MD and MDMS with dry maize grain contained more starch than diets for the other groups, especially that for group B with barley as the source of starch (Table 1).

Concentrate mixtures for calves with maize in dry or ensiled form (groups $\mathrm{M}_{\mathrm{D}}, \mathrm{BM}_{\mathrm{S}}, \mathrm{M}_{\mathrm{D}} \mathrm{M}_{\mathrm{S}}$ ) contained more oleic acid (C18:1) and had a higher MUFA/SFA ratio compared to the control mixture with barley (B) (Table 2).

Table 2. Major fatty acids of mixtures for veal calves, $\mathrm{g} / 100 \mathrm{~g}$ total FA

\begin{tabular}{|c|c|c|c|c|c|}
\hline \multirow{2}{*}{ Fatty acid } & \multicolumn{4}{|c|}{ Groups $^{1}$} & \multirow{2}{*}{$\begin{array}{l}\text { Milk } \\
\text { replacer }\end{array}$} \\
\hline & B & $M_{D}$ & $\mathrm{BM}_{\mathrm{s}}$ & $\mathrm{M}_{\mathrm{D}} \mathrm{M}_{\mathrm{s}}$ & \\
\hline$\overline{C_{10}}$ & 0.00 & 0.01 & 0.00 & 0.00 & 0.00 \\
\hline $\mathrm{C}_{12.0}^{10: 0}$ & 0.09 & 0.05 & 0.29 & 0.77 & 0.00 \\
\hline $\mathrm{C}_{14: 0}^{12: 0}$ & 0.32 & 0.16 & 0.34 & 0.47 & 3.81 \\
\hline $\mathrm{C}_{16: 0}^{14: 0}$ & 24.71 & 17.82 & 18.00 & 16.8 & 30.95 \\
\hline $\mathrm{C}_{16: 1}^{10: 0}$ & 0.19 & 0.21 & 0.09 & 0.07 & 0.44 \\
\hline $\mathrm{C}_{18.0}$ & 0.00 & 0.00 & 1.76 & 1.86 & 7.38 \\
\hline $\mathrm{C}_{18: 1}^{18: 0}$ & 20.84 & 27.23 & 28.4 & 32.19 & 39.36 \\
\hline $\mathrm{C}_{18: 2^{\prime}{ }^{\mathrm{n}-6}-6}$ & 49.62 & 51.45 & 46.17 & 43.96 & 10.04 \\
\hline$C_{18: 3}{ }^{n-3}$ & 3.67 & 2.41 & 2.64 & 1.78 & 0.45 \\
\hline$C_{20.0}$ & 0.00 & 0.22 & 0.64 & 0.82 & 0.44 \\
\hline $\mathrm{C}_{20.4}^{20.0}$ & 0.00 & 0.00 & 0.05 & 0.04 & 0.00 \\
\hline $\mathrm{C}_{22.0}^{2.0}$ & 0.00 & 0.00 & 0.16 & 0.16 & 0.09 \\
\hline $\mathrm{C}_{22: 1}^{2: 1}$ & 0.18 & 0.14 & 0.64 & 0.5 & 0.00 \\
\hline Other FA & 0.38 & 0.3 & 0.82 & 0.58 & 7.04 \\
\hline SFA & 25.13 & 18.26 & 21.19 & 20.88 & 42.67 \\
\hline UFA & 74.49 & 81.44 & 77.99 & 78.54 & 50.29 \\
\hline MUFA & 21.21 & 27.58 & 29.13 & 32.76 & 39.8 \\
\hline MUFA/SFA & 0.84 & 1.51 & 1.37 & 1.57 & 0.93 \\
\hline PUFA & 53.29 & 53.87 & 48.86 & 45.78 & 10.49 \\
\hline PUFA/SFA & 2.12 & 2.97 & 2.31 & 2.19 & 0.25 \\
\hline$n-3$ & 3.67 & 2.41 & 2.64 & 1.78 & 0.45 \\
\hline$n-6$ & 49.62 & 51.46 & 46.22 & 44.00 & 10.04 \\
\hline$n-6 / n-3$ & 13.52 & 21.31 & 17.57 & 24.72 & 22.31 \\
\hline
\end{tabular}

SFA - saturated FA; MUFA - monounsaturated FA; PUFA - polyunsaturated FA; ${ }^{1}$ see Table 1 


\section{Chemical composition of meat}

No differences were found between the groups in the nutrient content of Musculus longissimus thoracis (MT), although in group MD the level of intramuscular fat was higher in comparison with the other groups $(\mathrm{P}>0.05$; Table 3$)$.

The starch source in concentrate mixtures for calves had an effect on the fatty acid profile of veal meat fat (Table 4). The fat of calves from groups fed ensiled maize grain had lower SFA and higher UFA contents compared with calves from

Table 3. Chemical composition of veal meat, \%

\begin{tabular}{|c|c|c|c|c|c|c|}
\hline \multirow{2}{*}{ Nutrients } & \multicolumn{4}{|c|}{ Groups ${ }^{1}$} & \multirow{2}{*}{$\mathrm{P}$} & \multirow{2}{*}{ SE } \\
\hline & $\mathrm{B}$ & $\mathrm{M}_{\mathrm{D}}$ & $\mathrm{BM}_{\mathrm{S}}$ & $\mathrm{M}_{\mathrm{D}} \mathrm{M}_{\mathrm{S}}$ & & \\
\hline Dry matter & 21.74 & 22.22 & 22.08 & 21.83 & 0.66 & 0.143 \\
\hline Ash & 1.08 & 1.06 & 1.08 & 1.1 & 0.24 & 0.007 \\
\hline Protein & 19.5 & 20.26 & 20.26 & 19.79 & 0.39 & 0.182 \\
\hline Ethanol extract & 0.91 & 1.01 & 0.94 & 0.79 & 0.83 & 0.077 \\
\hline
\end{tabular}

$\mathrm{SE}$ - standard error of the mean; without letters - $\mathrm{P}>0.05 ;{ }^{1}$ see Table 1

Table 4. Major fatty acids of veal intramuscular fat, $\mathrm{g} / 100 \mathrm{~g}$ total FA

\begin{tabular}{|c|c|c|c|c|c|c|}
\hline \multirow[b]{2}{*}{ Fatty acids } & \multicolumn{4}{|c|}{ Grouns ${ }^{1}$} & \multirow[b]{2}{*}{$\mathrm{P}$} & \multirow[b]{2}{*}{ SE } \\
\hline & B & $M_{D}$ & $\mathrm{BM}_{\mathrm{s}}$ & $\mathrm{M}_{\mathrm{D}} \mathrm{M}_{\mathrm{S}}$ & & \\
\hline$\overline{\mathrm{C}_{8.0}}$ & 0.00 & 0.00 & 0.04 & 0.05 & 0.58 & 0.02 \\
\hline $\mathrm{C}^{8: 0}$ & 0.009 & 0.004 & 0.00 & 0.00 & 0.53 & 0.002 \\
\hline $\mathrm{C}_{100}^{10: 0}$ & 0.73 & 0.25 & 0.22 & 0.19 & 0.39 & 0.12 \\
\hline $\mathrm{C}_{140}^{12: 0}$ & 3.57 & 2.16 & 2.37 & 1.95 & 0.61 & 0.44 \\
\hline $\mathrm{C}^{14: 0}$ & $27.48^{\mathrm{a}}$ & $24.18^{\mathrm{ab}}$ & $22.1^{\mathrm{b}}$ & $20.5^{\mathrm{b}}$ & 0.02 & 0.9 \\
\hline $\mathrm{C}^{16: 0}$ & 2.08 & 2.06 & 2.32 & 2.5 & 0.59 & 0.13 \\
\hline$C_{18: 0}^{16: 1}$ & 13.26 & 14.07 & 13.32 & 13.73 & 0.74 & 0.27 \\
\hline $\mathrm{C}_{18 \cdot 1}^{18: 0}$ & 27.62 & 31.69 & 29.15 & 28.15 & 0.56 & 1.04 \\
\hline $\mathrm{C}_{18: 1}^{18,2}$ & 18.19 & 18.44 & 19.25 & 19.98 & 0.97 & 1.31 \\
\hline $\mathrm{C}_{18.2,3}^{1-0}$ & 0.12 & 0.1 & 0.15 & 0.17 & 0.57 & 0.02 \\
\hline $\mathrm{C}_{18 \cdot 3,{ }^{n-3}}^{1,3}$ & 0.44 & 0.41 & 0.5 & 0.44 & 0.46 & 0.02 \\
\hline $\mathrm{C}_{20 \cdot 0}^{18: 3^{3} \mathrm{n}-3}$ & $0.08^{\mathrm{b}}$ & $0.15^{\mathrm{ab}}$ & $0.24^{\mathrm{a}}$ & $0.24^{\mathrm{a}}$ & 0.03 & 0.02 \\
\hline $\mathrm{C}_{20: 4}^{20: 0}{ }^{n-6}$ & 6.0 & 5.79 & 8.5 & 9.83 & 0.1 & 0.7 \\
\hline $\mathrm{C}_{20: 5}^{20: 4^{\prime}, \mathrm{n}-3}, \mathrm{EPA}$ & $0.19^{\mathrm{B}}$ & $0.16^{\mathrm{B}}$ & $0.47^{\mathrm{A}}$ & $0.57^{\mathrm{A}}$ & $<0.01$ & 0.05 \\
\hline $\mathrm{C}_{22 \cdot 0}^{20: 5^{\prime} \mathrm{n}-3^{\prime}}$ & 0.00 & 0.00 & 0.05 & 0.08 & 0.19 & 0.02 \\
\hline $\mathrm{C}_{22: 1}^{22: 0}$ & $0.01^{\mathrm{B}}$ & $0.01^{\mathrm{B}}$ & $0.08^{\mathrm{A}}$ & $0.09^{\mathrm{A}}$ & $<0.01$ & 0.01 \\
\hline $\mathrm{C}^{22: 1}$, DHA & $0.05^{\text {B }}$ & $0.16^{\mathrm{B}}$ & $0.45^{\mathrm{A}}$ & $0.59^{\mathrm{A}}$ & $<0.01$ & 0.06 \\
\hline Other FA & $0.17^{\mathrm{B}}$ & $0.37^{\mathrm{B}}$ & $0.79^{\mathrm{A}}$ & $0.94^{\mathrm{A}}$ & $<0.01$ & 0.1 \\
\hline SFA & 45.13 & 40.8 & 38.34 & 36.74 & 0.12 & 1.33 \\
\hline UFA & 54.75 & 58.82 & 60.88 & 62.32 & 0.19 & 1.29 \\
\hline MUFA & 29.71 & 33.76 & 31.55 & 30.74 & 0.64 & 1.08 \\
\hline MUFA/SFA & $0.68^{\mathrm{b}}$ & $0.83^{\mathrm{a}}$ & $0.82^{\mathrm{a}}$ & $0.84^{\mathrm{a}}$ & 0.03 & 0.03 \\
\hline PUFA & 24.99 & 25.39 & 29.31 & 31.58 & 0.64 & 1.98 \\
\hline PUFA/SFA & 0.55 & 0.63 & 0.8 & 0.86 & 0.49 & 0.07 \\
\hline$n-3$ & $0.68^{\mathrm{B}}$ & $0.73^{\mathrm{B}}$ & $1.42^{\mathrm{A}}$ & $1.60^{\mathrm{A}}$ & $<0.01$ & 0.12 \\
\hline$n-6$ & 24.31 & 24.33 & 27.90 & 29.68 & 0.73 & 1.91 \\
\hline$n-6 / n-3$ & $34.78^{\mathrm{a}}$ & $34.87^{\mathrm{a}}$ & $19.8^{\mathrm{b}}$ & $18.78^{\mathrm{b}}$ & 0.02 & 2.69 \\
\hline
\end{tabular}

SFA - saturated FA; MUFA - monounsaturated FA; PUFA - polyunsaturated FA; SE - standard error of the mean, without letters $-\mathrm{P}>0.05 ;{ }^{\mathrm{a}, \mathrm{b}, \mathrm{c}}-\mathrm{P} \leq 0.05{ }^{\mathrm{A}, \mathrm{B}, \mathrm{C}}-\mathrm{P} \leq 0.01 ;^{1}$ see Table 1 
groups receiving barley or dry maize grain $(\mathrm{B}, \mathrm{MD})$, but the differences were not significant $(\mathrm{P}=0.12)$. Fat in meat from calves fed with maize grain (dry or ensiled) had a lower MUFA/SFA ratio ( 0.68 vs $0.83 \pm 0.01 ; \mathrm{P}=0.03$ ). Feeding diets with maize grain, in particular ensiled maize grain, markedly decreased the concentration of $\mathrm{C} 16: 0(\mathrm{P}=0.02)$ and increased the concentrations of $\mathrm{C} 20: 0(\mathrm{P}=0.03)$ and $\mathrm{C} 22: 0$ $(\mathrm{P}=0.19)$ in $\mathrm{MT}$ fat compared with the control group. No significant differences were found between the groups in the concentration of linoleic $(\mathrm{C} 18: 2, \mathrm{n}-6)$ and linolenic acids (C18:3; $\mathrm{n}-3)$, whereas calves fed mixtures containing ensiled maize grain were characterized, compared with calves receiving barley $(\mathrm{B})$ or dry maize grain (MD) diets, by a significantly higher content of eicosapentaenoic (EPA; C20:5, n-3), docosaxehaenoic (DHA; C22:6; n-3) and docosanoic acids (C22:1), and a lower $n-6 / n-3$ PUFA ratio $(\mathrm{P}<0.01)$ in meat fat.

\section{Physicochemical and organoleptic evaluation of meat}

The starch sources had no effect $(\mathrm{P}>0.05)$ on cooking loss or on $\mathrm{pH}$ measured $24 \mathrm{~h}$ and 7 days after slaughter. There were no differences among the groups in the other physicochemical characteristics of meat, i.e. tenderness and colour (Table 5). After a week of storage, the meat had a lighter colour (increased $L$ value),

Table 5. Physicochemical and sensory properties of Musculus longissimus thoracis, $\%$

\begin{tabular}{|c|c|c|c|c|c|c|}
\hline \multirow{2}{*}{ Properties } & \multicolumn{4}{|c|}{ Groups $^{1}$} & \multirow{2}{*}{$\mathrm{P}$} & \multirow{2}{*}{ SE } \\
\hline & B & $\mathrm{M}_{\mathrm{D}}$ & $\mathrm{BM}_{\mathrm{S}}$ & $\mathrm{M}_{\mathrm{D}} \mathrm{M}_{\mathrm{S}}$ & & \\
\hline \multicolumn{7}{|l|}{ Physicochemical properties } \\
\hline thermal loss, $\%$ & 23.14 & 23.44 & 21.82 & 23.83 & 0.33 & 1.21 \\
\hline tenderness, $\mathrm{kg} / \mathrm{cm}^{2}$ & 12.03 & 11.34 & 11.64 & 13.28 & 0.74 & 0.63 \\
\hline $\mathrm{pH}, 24 \mathrm{~h}$ after slaughter & 5.62 & 5.68 & 5.64 & 5.59 & 0.36 & 0.01 \\
\hline $\mathrm{pH}$, week after slaughter & 5.45 & 5.50 & 5.48 & 5.44 & 0.70 & 0.02 \\
\hline \multicolumn{7}{|l|}{ Colour, 24 h after slaughter } \\
\hline lightness $(L)$ & 47.05 & 46.88 & 47.22 & 46.96 & 0.85 & 0.40 \\
\hline redness $(a)$ & 19.85 & 19.63 & 19.91 & 20.14 & 0.88 & 0.30 \\
\hline yellowness (b) & 3.21 & 2.48 & 3.30 & 4.11 & 0.49 & 0.48 \\
\hline \multicolumn{7}{|l|}{ Colour, 7 days after slaughter } \\
\hline lightness $(L)$ & 48.48 & 47.19 & 48.16 & 49.51 & 0.46 & 0.51 \\
\hline redness $(a)$ & 17.32 & 18.39 & 17.98 & 17.98 & 0.83 & 0.41 \\
\hline yellowness $(b)$ & 3.38 & 4.91 & 4.30 & 4.84 & 0.60 & 0.44 \\
\hline \multicolumn{7}{|l|}{ Sensory properties } \\
\hline texture & 3.75 & 3.25 & 3.5 & 3.0 & 0.38 & 0.15 \\
\hline aroma intensity & 3.75 & 3.25 & 3.5 & 3.0 & 0.17 & 0.13 \\
\hline aroma desirability & $4.0^{\mathrm{a}}$ & $4.0^{\mathrm{a}}$ & $3.25^{\mathrm{b}}$ & $3.0^{\mathrm{b}}$ & 0.02 & 0.16 \\
\hline tenderness & 3.75 & 4.0 & 3.75 & 3.75 & 0.91 & 0.14 \\
\hline juiciness & 4.0 & 3.5 & 3.25 & 3.75 & 0.38 & 0.16 \\
\hline taste intensity & 3.75 & 4.0 & 4.0 & 4.0 & 0.43 & 0.06 \\
\hline taste desirability & 4.25 & 3.75 & 4.0 & 4.0 & 0.31 & 0.09 \\
\hline
\end{tabular}


lower redness (decreased $a$ value), and higher yellowness. Higher yellowness was observed in meat from calves receiving both dry and ensiled maize compared with barley-fed calves.

\section{DISCUSSION}

Chemical composition of meat. In the present study the basic chemical composition of Musculus longissimus thoracis was relatively stable with some minor changes in intramuscular fat content, which corresponded to the results of other researchers. The absence of differences in the effect of barley and maize starch on the chemical composition of meat was also reported by Fiems et al. (1999). The dry matter and protein content of meat is relatively stable (Geay et al., 2001). The content and composition of fat deposited in meat may depend on the type of ration, its energy content, digestibility, intestinal absorption, liver metabolism, and lipid transport in muscle (Geay et al., 2001; Di Luccia et al., 2003). Sami et al. (2006) obtained an increase in intramuscular fat content of meat from maize-fed animals (1.96 vs $1.54 \%)$. According to the same authors, maize as a source of slowly degradable starch may contribute to an increase in meat fat content. Hideaki et al. (1998), who investigated the effect of barley- or maize-based concentrate mixtures on fatness and quality of meat from Japanese Black $\times$ Holstein-Friesian fattening bulls, found a slightly higher content of intramuscular fat and higher marbling of meat (1.5 points higher according to the Beef Marbling Standard) when barley was used, and maize starch increased the content of subcutaneous fat.

Fatty acid profile of veal meat fat. Changes in the fatty acid profile of veal meat could be influenced by the high amounts of concentrates fed. Concentrate feeds are rich sources of fatty acids, and when high amounts of concentrates are fed to calves, the starch rate and place of degradation can influence rumen $\mathrm{pH}$ and thus reduce lipolysis and biohydrogenation (Doreau and Ferlay, 1994). In our study, a significant $(\mathrm{P}<0.01)$ decrease in the $\mathrm{pH}$ of rumen contents in calves from groups BMS and MDMS was observed $(\mathrm{pH}=5.2$ and 5.0) compared with group MD ( $\mathrm{pH}=6.26)$ (Sosin-Bzducha et al., 2010). Reducing the rumen content $\mathrm{pH}$ to below 6 decreases biohydrogenation by $5 \%$ and lipolysis by $20 \%$ (Van Nevel and Demeyer, 1996). Thus, the low $\mathrm{pH}$ may account for increased unsaturation of fatty acids in rumen contents and amount of duodenal lipids (Kobayashi et al., 1992) and increased amount of deposited fat in animals given concentrate feeds (Demeyer and Doreau, 1999). Feeding large amounts of concentrates to young animals, which deposit less subcutaneous fat than adult animals, may considerably increase the amount of polyunsaturated fatty acids in intramuscular fat. The increase in total unsaturated fatty acids in the groups of calves fed diets with 
ensiled maize was due to a highly significant increase in n-3 acids, in particular eicosapentaenoic (EPA; C20:5) and docosaxehaenoic acids (DHA; C22:6), and to an increase in $n-6$ acids, in particular arachidonic acid (AA; $\mathrm{C} 20: 4)(\mathrm{P}=0.10)$ in the analysed meat samples. With no differences in the concentration of linoleic $(\mathrm{C} 18: 2 ; \mathrm{n}-6)$ and linolenic acids $(\mathrm{C} 18: 3 ; \mathrm{n}-3)$, which are considered precursor compounds in the synthesis of AA, EPA and DHA, the thesis that the lower $\mathrm{pH}$ in BMS and MDMS decreased the degree of biohydrogenation and increased the flow of n-3 precursors to the intestine may be true. Doreau et al. (1997) report that the degree of biohydrogenation of 18-carbon polyunsaturated fatty acids (C18 PUFA) is lower when diets with a large proportion of concentrates are fed.

In groups BMS and MDMS, a several percent decrease in hyperholesterolaemic palmitic acid $(\mathrm{C} 16: 0)$ was noted $(\mathrm{P}<0.05)$. The highest proportion of palmitic acid was found in meat from calves receiving the barley diet (Table 4). Barley contains relatively greater amounts of this acid compared with maize, however. The higher percentage of arachidic acid (C20:0) in meat from maize-fed calves is probably due to the higher content of this acid in maize diets. Small amounts of C20:0 did not have such a large effect on total SFA as changes in the content of palmitic acid. Wismer et al. (2008), who fed maize to calves, observed a tendency towards lower concentrations of saturated fatty acids (SFA; $\mathrm{P}=0.08$ ), with no differences in monounsaturated (MUFA) and polyunsaturated fatty acids (PUFA). When giving maize in mixtures for fattening bulls, Hideaki et al. (1998) obtained a higher SFA content in meat fat and in subcutaneous fat compared with barley. Geay et al. (2001) report the PUFA-to-SFA ratio in beef or mutton to range from 0.11 to 0.15 , which is about three times lower than recommended for the human diet $(0.45)$ (Wood and Enser, 1997). In our study, the PUFA-to-SFA ratio was higher in all of the groups: 0.76 and 0.86 in groups BMS and MDMS, and 0.55 and 0.62 in groups $B$ and MD, respectively. The two-fold increase in n-3 acids decreased the n-6/n-3 ratio almost by half and, although the level obtained is still far from optimal for consumer health, it considerably improves the nutritional value of the meat.

The differences found between the groups in undetermined fatty acids may result from the increased proportion in total acids of CLA, which could not be conclusively isolated due to the equipment used for quantitative determination (column of $25 \mathrm{~m}$ length).

Physicochemical and organoleptic evaluation of meat. The changes observed during storage of meat are probably associated with aging and post-mortem acidification. An aging-related decrease in the $\mathrm{pH}$ of meat was observed in all the groups. Post-mortem increase in lactic acid production, which lowers $\mathrm{pH}$ value, lightens meat colour. Wismer et al. (2008) found no differences, and Boles et al. $(2004,2005)$ reported a slight tendency towards changes in the colour of meat from fattening bulls fed maize and different barley cultivars. The meat from maize-fed 
animals showed a clear tendency $(\mathrm{P}=0.08)$ towards higher redness. In response to feeding maize, a tendency was also observed $(\mathrm{P}=0.09)$ towards subcutaneous fat becoming more yellow. In another experiment by the same team (Boles et al., 2005), after 10 days of storage the meat from animals fed barley cultivar Logan $(a=24.06)$ was less red than the meat of animals receiving cultivar Chincok $(a=26.4)$ or maize $(a=26.14)$. The meat exhibited no differences in structure, tenderness, or juiciness. In the experiment under discussion, tenderness measured mechanically and by a sensory panel did not differ between the groups. The lack of differences in tenderness was also reported by Boles et al. (2005), who compared the effect of barley and maize starch. No statistically significant differences were found for taste, while the meat from calves in groups in which half of barley grain or dry maize grain was replaced with ensiled high-moisture grain showed a similar taste intensity, but the aroma of roasted meat was poorer in groups BMS and MDMS compared with groups B and MD. The less desirable aroma of meat in groups BMS and MDMS could be due to the higher PUFA content of fat or n-6-to-n-3 PUFA ratio. While SFA are more stable as they become oxidized at high temperatures, PUFA may be oxidized in raw meat or at low temperatures. PUFA oxidation products may cause an unpleasant odour in meat (Doreau and Chiliard, 1997; Geay et al., 2001). Farmer (1994) reports that the n-6-to-n-3 ratio may also contribute to a change in meat aroma. Nonetheless, the meat from groups BMS and MDMS was not observed to have a poorer taste, or more or less intense flavour or aroma.

\section{CONCLUSIONS}

The use of maize in both dry and moist ensiled form had a beneficial effect on the fatty acid profile of meat by increasing the proportion of monounsaturated and polyunsaturated fatty acids at the cost of saturated fatty acids. The decrease in fatty acid saturation in the groups fed ensiled maize grain is most probably the result of lower lipolysis and biohydrogenation, which is caused by a reduction in rumen content $\mathrm{pH}$ in these groups. The use of ensiled maize grain had a negative effect on the aroma of the meat, probably due to its effect on the fatty acid profile of intramuscular fat. Starch sources had no effect on the physicochemical characteristics of meat, i.e. tenderness and colour.

\section{REFERENCES}

Archibeque S.L., Miller D.N., Freetly H.C., Ferrell C.L., 2006. Feeding high-moisture corn instead of dry-rolled corn reduces odorous compound production in manure of finishing beef cattle without decreasing performance. J. Anim. Sci. 84,1767 (Abstr.) 
AOAC, 1997. Association of Official Analytical Chemists, Official Methods of Analysis. $16^{\text {th }}$ Edition. Arlington, VA

Baryłko-Pikielna N., 1975. An Outline of the Sensory Evaluation of Food (in Polish). WNT, Warsaw

Boccard R., Buchter L., Casteels E., Cosentino E., Dransfield E., Hood D.E., Joseph R.L., McDougall D.B., Rhodes D.N., Schrön I., Timbergen B.J., Touraille C., 1981. Procedures for measuring meat quality characteristics in beef production experiments. Report of a Working group in the Commission of the European Communities (CEC), Beef Production Research Programme. Livest. Prod. Sci. 8, 385-397

Boles J.A., Bowman J.G., Boss D.L., Surber L.M.M., 2005. Meat color stability affected by barley variety fed in finishing diet to beef steers. Meat Sci. 70, 633-638

Boles J.A., Bowman J.G., Surber L.M.M., Boss D.L., 2004. Effects of barley variety fed to steers on carcass characteristics and color of meat. J. Anim. Sci. 82, 2087-2091

Demeyer D., Doreau M., 1999. Targets and procedures for altering ruminant meat and milk lipids. Proc. Nutr. Soc. 58, 1-15

Di Luccia A., Satriani A., Baron C.M.A., Colatruglio P., Gigli S., Occidente M., Trivellone E., Zullo A., Matassino D., 2003. Effect of dietary energy content on the intramuscular fat depots and triglyceride composition of river buffalo meat. Meat Sci. 65, 1379-1389

Doreau M., Chilliard Y., 1997. Digestion and metabolism of dietary fat in farm animals. Brit. J. Nutr. 78, Suppl. 1, S15-S35

Doreau M., Demeyer D.,Van Nevel C.J., 1997. Transformation and effects of unsaturated fatty acids in the rumen. Consequences of milk fat secretion. In: R.A.S. Welch, D.J.W. Burns, S.R. Davis, A.I. Popay, C.G. Prosser (Editors). Milk Composition, Production and Biotechnology. CAB International, New York, pp. 73-92

Doreau M., Ferlay A., 1994. Digestion and utilization of fatty acids by ruminants. Anim. Feed Sci. Tech. 45, 379-396

Farmer L.J., 1994. The role of nutrients in meat flavour formation. Proc. Nutr. Soc. 53, 327-333

Fiems L.O., De Campeneere S., Cottyn B.G., Vanacker J.M., D’Heer B.G., Boucque Ch. V., 1999. Effect of amount and degradability of dietary starch on animal performance and meat quality of beef bulls. J. Anim. Physiol. Anim. Nutr. 82, 217-226

Geay Y., Bauchart D., Hocquette J.F., Culioli J., 2001. Effect of nutritional factors on biochemical, structural and metabolic characteristic of muscles in ruminants, consequences on dietetic value and sensorial qualities of meat. Reprod. Nutr. Develop. 41, 1-26

Hideaki T., Hidekazu O., Hiroshi M., Masakazu N., Nasako M., 1998. Effect of barley and corn feeding on fattening performance and meat quality from cross-bred (Japanese black x Holstein) steers. Res. Bul. Aichi-ken Agric. Res. Center 30, 289-293

Hocquette J.F., Beauchart D., 1999. Intestinal absorption, blood transport and hepatic and muscle metabolism of fatty acids in preruminant and ruminant animals. Reprod. Nutr. Develop. 39, $27-48$

Huntington G.B., 1997. Starch utilization by ruminants: From basics to the bunk. J. Anim. Sci. 75, $852-867$

Knowlton K.F., Glenn B.P., Erdman R.A., Wilkerson V.A., 2000. The high moisture advantage: Greater than we thought. Hoard's Dairyman, October 25, 728-733

Kobayashi Y., Wakita M., Hoshino S., 1992. Effects of the ionophore salinomycin on nitrogen and long-chain fatty acids profiles of digesta in the rumen and duodenum of sheep. Anim. Feed Sci. Tech. 36, 67-76

Sami A.S., Koegel J., Eichinger H., Freudenreich P., Schwarz J., 2006. Effects of the dietary energy source on meat quality and eating quality attributes and fatty acid profile of Simmental bulls. Anim. Res. 55, 287-299 
SAS, 2002. Version 4.0, Sas Institute Inc. Cary, NC

Skrzyński G., Szarek J., Strzetelski J., Zapletal P., Adamczyk K., 2001. Physicochemical and organoleptic quality of meat from crossbred bulls (in Polish). Rocz. Nauk. Zoot., Suppl. 12, 235-246

Sosin-Bzducha E.M., Strzetelski J.A., Borowiec F., Kowalczyk J., Okoń K., 2010. Effect of feeding ensiled maize grain on rumen development and calf performance. J. Anim. Feed Sci. 19, 195-210

Van Nevel C.J., Demeyer D.I., 1996. Effect of $\mathrm{pH}$ on biohydrogenation of polyunsaturated fatty acids and their Ca-salts by rumen microorganisms in vitro. Arch. Anim. Nutr. 49, 151-158

Wismer W., Okine E.K., Stein A., Seibel M.R., Goonewardene L.A., 2008. Physical and sensory characterization and consumer preference of corn and barley-fed beef. Meat Sci. 80, 857-863

Wood J.D., Enser M., 1997. Factors influencing fatty acids in meat and the role of antioxidants in improving meat quality. Brit. J. Nutr. 77, Suppl. 1, S49-S60 